\title{
Management, Abolition, and Nullification: Nuclear Nonproliferation Strategies in the 21st Century
}

\author{
ROBERT AySON ${ }^{1}$
}

Robert Ayson teaches international relations at Massey University, Palmerston North, New Zealand. He has served as adviser to the New Zealand Parliamentary Select Committee on Foreign Affairs, Defense and Trade. His articles on strategic theory, New Zealand disarmament policy, and New Zealand regional security policy have appeared in The Journal of Strategic Studies, International Journal, and Contemporary Southeast Asia.

A s the 21 st century opens, the international community must choose how to address the continuing challenges posed by nuclear proliferation. Roughly speaking, there are three main strategies available for tackling these challenges. The first of these is the "management" strategy, which relies upon arms control as its main instrument, including the international nonproliferation regime built around the 1968 Treaty on the NonProliferation of Nuclear Weapons (NPT). The second is the "abolition" strategy, which sees the control of nuclear proliferation as a step down the road towards complete nuclear disarmament, an approach that emphasizes the commitment to that end contained in Article VI of the NPT. The third is the "nullification" strategy that advocates military counter-measures, such as missile defense systems, to cancel out the capabilities and threats that arise from proliferation.

Until recently, the management strategy appeared to offer the best basis for achieving an international consensus on dealing with nuclear proliferation problems. However, this strategy has come under increasing pressures since the mid-1990s. These pressures include the failure of the nonproliferation regime to prevent Pakistani and Indian nuclear tests in 1998, concerns about proliferation- related threats on the Korean Peninsula and in the Middle East, and U.S. plans for an ambitious system of national missile defense (NMD) and theater missile defense (TMD). ${ }^{2}$ These developments have provided encouragement to advocates of the other two strategies, abolition and nullification. It may be, however, that none of these three strategies alone can provide the basis for effectively addressing contemporary nuclear proliferation challenges. Instead, the international community may need to consider new and innovative ways of mixing these three strategies into new hybrid strategies.

This article examines the prospects of the three traditional approaches to nonproliferation: management, abolition, and nullification. It analyzes the key successes and failures of each approach, and assesses their current support. The article also considers the prospects for mixed strategies that combine elements of more than one of these three approaches. In particular, the potential for cooperation between the respective arguments of missile defense advocates, who espouse a variant of the nullification strategy, and disarmament activists, who strive for abolition, will be assessed. Although these approaches at first seem incompatible, upon closer examination some potential synergies emerge. Throughout, the article draws comparisons 
between the policy stances of New Zealand, a country that tends to support the eventual abolition of nuclear weapons through international legal mechanisms, and those of the United States, where missile defense has gained political support at the potential expense of multilateral arms control.

\section{NUCLEAR PROLIFERATION TODAY}

Nuclear proliferation and the spread of related technologies and other weapons of mass destruction (WMD), such as ballistic missiles, feature prominently in many analyses of the post-Cold War security environment. U.S. assessments of the global strategic situation are particularly concerned with this issue. The 1998 edition of the United States National Security Strategy, for example, offers the general assessment that "weapons of mass destruction pose the greatest potential threat to global stability and security." Similarly, a December 2000 Central Intelligence Agency National Intelligence Council report into long-term global trends argued: "The probability that a missile armed with WMD would be used against U.S. forces or interests is higher today than during most of the Cold War and continues to grow."

Internationally, the concerns expressed about the consequences of nuclear proliferation are many and varied. These worries range from the general notion that more fingers on the nuclear trigger raises the mathematical probability of a war involving nuclear weapons to fears that the presence of nuclear weapons may undermine security in already volatile regions. A range of the main concerns associated with nuclear proliferation is presented in Table 1.

\section{Table 1: Some Standard Concerns Associated With Nuclear Proliferation}

Problem

More fingers on the nuclear trigger

Dangerous fingers on the nuclear trigger

Nuclear terrorism

Leakage of nuclear materials, technology \& expertise

Unreliable or inadequate organizations and infrastructures responsible for nuclear weapons

Arms races encouraged

Regional stability reduced

Intercontinental threat (e.g., to the United States)

Nonproliferation regime undermined
Potential Examples

Any new nuclear weapon state ${ }^{1}$

North Korea, Iraq, and other "rogue states"2

Sub-state actors with potential access to nuclear weapons/technology $\mathrm{y}^{3}$

From former Soviet republics ${ }^{4}$

India, Pakistan ${ }^{5}$

Between India and Pakistan; ${ }^{6}$ throughout the Asia-Pacific region ${ }^{7}$

South Asia, North Asia, and Middle East ${ }^{8}$

North Korea, Iraq, Iran ${ }^{9}$

Any new nuclear weapon state ${ }^{10}$ 
Many of these concerns were heightened when India and Pakistan conducted tit-for-tat nuclear tests in 1998, thereby bringing their existing nuclear weapons capabilities firmly out of the closet. ${ }^{15}$ The highly publicized emergence of these two South Asian competitors as undeniable possessors of nuclear weapons-if not as fully recognized nuclear weapon states (NWS) - meets the loose definition of nuclear proliferation that will be used in this article: an increase in the number of international actors who demonstrably possess nuclear weapons.

India and Pakistan are not the only Asian states that pose challenges to the nonproliferation regime. North Korea's test launch of a three-stage missile over Japan in August 1998 added to existing concerns (especially in Japan and the United States) about the status of Pyongyang's nuclear program. ${ }^{16}$ Moreover, while a long-standing member of the nuclear weapons club, China is putting quite some energy into modernizing its own capabilities. ${ }^{17}$ These Chinese activities are not unique, however, as there are also ongoing modernization-related activities in Russia and the United States, including subcritical testing and experimentation. ${ }^{18}$

Beijing's modernization program received particular attention courtesy of the allegations of Chinese nuclear espionage raised by the Cox Committee report issued by the U.S. Congress in 1999. ${ }^{19}$ The Chinese program could be further fueled by American plans to deploy TMD in Asia. ${ }^{20}$ China would react especially forcefully to a system that offers some measure of protection to Taiwan. Beijing may also be provoked by the Bush administration's sweeping approach to missile defense, which might pose some risk to the rather modest nuclear capabilities of China. ${ }^{21}$ On the whole, the Asia-Pacific region reflects a number of contemporary proliferation concerns. ${ }^{22}$ This point has been reflected as far south as Canberra where the 1997 strategic review issued by the Australian Department of Defense notes "the potential threat to Australia from ballistic and cruise missiles." 23

The Middle East is another area where proliferation risks generate continuing concern. The international community worked hard after the Gulf War to prevent Iraqi entry into the unofficial nuclear club, ${ }^{24}$ but the 1998 collapse of the United Nations Special Commission (UNSCOM) monitoring regime has severely hampered initiatives to thwart Saddam Hussein's bid for WMD. ${ }^{25}$ Moreover, at no time has the international community had a pretext to apply similarly intrusive measures to neighboring Iran, whose nuclear ambitions also trouble some observers. ${ }^{26}$
Coupled with widely acknowledged Israeli nuclear weapons capabilities, the closely watched nuclear ambitions of Baghdad and Teheran will continue to place this part of the world firmly on the nuclear proliferation map, ${ }^{27}$ especially to the extent that WMD capabilities in any one of these countries serves as an incentive to their acquisition and retention among the others. ${ }^{28}$

More generally, nuclear issues remain a significant element in the somewhat precarious post-Cold War position of Russia. Added to ongoing worries about the safety and security of Russia's huge but aging nuclear weapons infrastructure have been signs of willingness by its leaders to play the nuclear card as one of the remaining sources of Russian leverage in international politics. ${ }^{29}$ For example, in 1999 Viktor Chernomyrdin, the Russian envoy on the Kosovo issue, suggested in a Washington Post article that Russian unease with the strategy of the North Atlantic Treaty Organization (NATO) in the Balkans might dash hopes for further progress in the Strategic Arms Reduction Treaty (START) process. ${ }^{30}$ While still in power, former Russian President Boris Yeltsin showed that he was not averse to waving the rhetorical nuclear stick in response to Western criticism over Russian actions in Chechnya. Moreover, Russia's new national security doctrine, announced in January 2000 by Yeltsin's successor, Vladimir Putin, allows greater scope for the use of nuclear weapons than earlier pronouncements from Moscow. ${ }^{31}$

Despite these trends, not all is bleak for those hoping that nuclear weapons will increasingly be pushed to the sidelines of international relations. ${ }^{32}$ By both announcing and renouncing its nuclear weapons capabilities in 1993, South Africa engaged in what might be called "deproliferation." Also during the 1990s, a number of other states, including Brazil and Argentina, have backed away from the nuclear threshold and embraced nonproliferation norms that they previous rejected. Ukraine, Belarus and Kazakhstan faced a different challenge, inheriting nuclear weapons left on their soil after the collapse of the Soviet Union. All three decided to renounce nuclear weapons and transfer them to Russia. ${ }^{33}$ Among the NWS, the United States, Russia, Great Britain, and France have also deactivated and dismantled substantial numbers of nuclear weapons since the end of the Cold War. China is alone among the five official NWS not to have reduced its arsenal. Regardless of these reductions, however, the five original members of the nuclear weapons club have demonstrated little interest in rushing headlong into a program of complete nuclear disarmament. ${ }^{34}$ 
Of course, this last point concerns existing nuclear arsenals more than contemporary outbreaks of proliferation. It may seem odd that an article ostensibly devoted to the development of nuclear weapons by additional countries should take such an interest in countries that crossed the nuclear threshold decades ago. Yet in terms of the overall nuclear weapons agenda, any attempt to quarantine off further nuclear proliferation from these older issues has become increasingly problematic.

The situation may have seemed simpler in earlier times. One the one hand, in the first half of the Cold War, such was the concern about the stability of the East-West nuclear balance that entire treatises on nuclear strategy could be found which barely mentioned the " $n+1$ " problem. ${ }^{35}$ On the other hand, while proliferation-related concerns grew sufficiently in the 1960s to produce the NPT as the basis of the global nonproliferation regime, the NPT itself was based on a clear demarcation between the privileged five, who were permitted to engage in nuclear strategy, and the rest who were in danger of engaging in nuclear proliferation.

The early twenty-first century situation appears to lack such clarity. ${ }^{36}$ For instance, since the end of the Cold War, the aging Russian nuclear arsenal has been viewed as a proliferation risk as much as it has been regarded as a key element in the future development of nuclear deterrence.

37 The reverse may also apply to other countries. As time goes on, increasing attention will be focused on Indian nuclear strategy, not just on the precedent Indian nuclear testing has helped set for new rounds of nuclear proliferation. ${ }^{38}$ Traditional lines of analysis also appear to be blurred when considering responses to recent proliferation by regional powers. U.S. missile defense plans, for instance, threaten to upset old arms control relationships with Russia and China.

\section{THE MANAGEMENT STRATEGY}

This muddying of the waters has caused difficulties not just for the NPT, but also for the broader management strategy of which it is a major instrument. This strategy tends to assume the presence of nuclear weapons as a long-term feature of the international environment. This approach has its roots in the theory and practice of nuclear arms control during the Cold War, which sought to manage and stabilize the arms race rather than attempting to abolish it completely. ${ }^{39}$ In this view, the task confronting the international community is not so much to put the nuclear weapons genie back in its bottle, but to remove those aspects of the nuclear age that make catastrophic conflict especially likely.

This search for an armed but stable world is implicit in the Cold War era analyses of scholars like Thomas Schelling and Morton Halperin, who regarded arms control as "all forms of military cooperation between potential enemies in the interest of reducing the likelihood of war, its scope and violence if it occurs, and the political and economic costs of being prepared for it." ${ }^{40}$ Indeed, the idea of managing the arms race is quite compatible with some countries retaining nuclear weapons in the name of nuclear deterrence; a relationship that itself seeks to reduce the likelihood of war occurring in the first place. The classical nonproliferation agenda was not antagonistic to this assumption, but built on a mutual interest between Cold War adversaries, the United States, Britain and France on the one hand, and the Soviet Union and China on the other, in avoiding the further expansion of the club of which they were the founding members.

The management strategy has bequeathed a partially successful legacy to the post-Cold War world. While the risk of nuclear warfare cannot be mathematically removed as long as at least some nuclear weapons exist, the situation could well have been worse than it is today. First, arms control agreements between the superpowers-such as the Strategic Arms Limitations Talks (SALT) agreements - did manage to address some of the most worrying portions of the arsenals of both sides. Second, while it may not be easy to demonstrate the extent to which the nonproliferation regime has been directly responsible for preventing the further spread of nuclear weapons, it is even harder to find support for the proposition that the world would have been better without it. With the help of other arms control mechanisms such as the safeguards of the International Atomic Energy Agency, Nuclear-WeaponFree Zones, the Missile Technology Control Regime, and bilateral preventive measures such as the Agreed Framework devised by Washington to forestall a North Korean nuclear weapons program, the NPT has been a positive influence. Indeed, as is often pointed out, the rather modest number of countries who possess nuclear weapons today is a far cry from what some of the pessimistic forecasts of earlier decades would have suggested. ${ }^{41}$

Some of the wider political relationships that shaped the Cold War period were also a boost to the management strategy. Soviet control of Eastern Europe and U.S. security guarantees to Western European and East Asian 
allies restricted the rationale for independent nuclear arsenals (with the obvious exceptions of Britain and France)..$^{42}$ Moreover, the end of the Cold War has not generated significant reverse incentives for proliferation. The network of U.S. alliance relationships remains intact, and as former Eastern bloc countries aspire to European Union and NATO membership and recognition as mature liberal democracies, the appeal of acquiring nuclear weapons appears to be rather limited. ${ }^{43}$ According to analyst Bruno Tertrais, the 1996 NATO declaration that the alliance has no intention to base nuclear weapons in the territories of new member countries means that the Czech Republic, Poland and Hungary "have effectively been denuclearized in advance." 44

Yet serious doubts now afflict the management approach. On the one hand, there is less than universal confidence in the proposition that the stable nuclear deterrence sought during the Cold War can or ought to be achieved in relations with new proliferators such as North Korea. ${ }^{45}$ On the other hand, the situation facing the arms control side of the management equation as the 21 st century begins is perhaps even less promising. This outcome is somewhat puzzling, considering the optimism of the early 1990s. At that time, the START process appeared to have a very good chance of pushing U.S. and Russian postures in the direction of minimum deterrence. There also seemed to be big gains available multilaterally, with the UN no longer paralyzed by the East-West divide. Indeed, in 1995 the NPT was extended indefinitely, and in 1996 the drafting of the Comprehensive Test Ban Treaty (CTBT) was completed.

But events since then have indicated the fragility of the situation. While neither India nor Pakistan are parties to the NPT, their 1998 tests have posed a serious external challenge to the nonproliferation regime. ${ }^{46}$ Internal challenges to the regime- posed by the nuclear weapons programs of NPT members Iran, Iraq, and North Korea-also persist. Moreover, the 1999 refusal of the U.S. Senate to ratify the CTBT is but one indication of the obstacles that hinder further movement on multilateral nuclear arms control. ${ }^{47}$

\section{THE STRATEGY OF ABOLITION}

Historians writing about this period in time to come may conclude that the arms control community over-reached in the 1990s. But they might also note signs of an increasing shift in emphasis from arms control to disarmament, from the idea of removing the world of the most dangerous aspects of the nuclear age to the idea of ending the age of nuclear weapons altogether. This approach suggests not a strategy of managing competition in nuclear armaments, but of abolishing nuclear weapons once and for all. ${ }^{48}$

It must be admitted that such an approach is far from novel. The 1946 Baruch Plan sought to end the nuclear arms race by signing nuclear weapons over to an international authority. ${ }^{49}$ In the ensuing decades, energetic campaigns (led by groups such as the Campaign for Nuclear Disarmament) raised concerns about the superpower nuclear confrontation and issued prominent calls for the abolition of nuclear weapons. But the international landscape of the post-Cold War period appears to have provided a rather large window of opportunity for the abolitionist cause, with more scope for envisaging international cooperation that might remove-rather than just manage - the nuclear legacies of the earlier age and forestall the creation of new nuclear rivalries.

Supporters of the abolitionist strategy, such as the New Zealand government, view their cause as an obligation rather than an option for the international community. To support their case, they point to the NPT itself, which includes a commitment on the part of the nuclear "haves" to eventually join everyone else as nuclear "have nots." Article VI of the NPT commits each party-both NWS and non-nuclear weapon states- to "pursue negotiations in good faith on effective measures relating to cessation of the nuclear arms race at an early date and to nuclear disarmament, and on a treaty on general and complete disarmament under strict and effective international control." 50 It was this very obligation that the International Court of Justice underscored (unanimously) in its 1996 ruling that using or threatening to use nuclear weapons was a violation of international law. ${ }^{51}$ For the proponents of nuclear weapons abolition, the idea of keeping a lid on the arms race through nonproliferation norms is not so much an end in itself, but rather a starting point towards the more ambitious goal of complete nuclear disarmament.

Abolitionists hold varying views about the timetable for achieving their not inconsiderable objective. ${ }^{52}$ Some have sought especially quick action. For example, at the 1995 NPT Review Conference, a series of disarmament groups met under the Abolition 2000 banner and called for negotiations on an international convention for the elimination of nuclear weapons to be concluded by the turn of the 21 st century. ${ }^{53}$ Other abolitionists favor a more gradual process of establishing a nuclear weapons-free world. ${ }^{54}$ In 1996, the Canberra Commission, a group of eminent 
authorities brought together by the Australian Labor Government then in office, delivered a clear call for the eventual elimination of nuclear weapons. ${ }^{55}$

While the election of a right-of-center administration under John Howard's leadership subsequently reduced Australian support for abolition, a small group of other countries, known as the New Agenda Coalition, has been strongly pushing the nuclear disarmament agenda at the United Nations. ${ }^{56}$ New Zealand is among the leading members of this group and has continued to draw on the strong anti-nuclear reputation it established in the mid1980s, when David Lange's Labor government prohibited port access to nuclear armed and powered vessels, thus triggering a crisis in security relations with Washington. New Zealand also played a leading role in the negotiation of the 1985 Treaty of Raratonga, which established the South Pacific Nuclear-Free Zone. New Zealand continued to campaign for nuclear disarmament under rightof-center governments during the 1990s, but efforts intensified with the November 1999 election of a left-ofcenter coalition government headed by Labor Party leader Helen Clark.

The new Clark government has committed itself to playing a prominent role in trying to kick-start the international disarmament process. For example, New Zealand played a significant role at the 2000 NPT Review Conference, helping secure an "unequivocal commitment" on the part of the NWS to meet their disarmament obligations under the Treaty. ${ }^{57}$ This policy was also reflected in March 2001, when Wellington hosted a United Nations Regional Disarmament Conference in Asia and the Pacific which reviewed global disarmament efforts, discussed the notion of a southern hemisphere free of nuclear weapons, and provided an opportunity for a range of Pacific Island countries to enhance their involvement in global disarmament treaties. ${ }^{58}$

But at the global level, much of the disarmament machinery is still in a rather poor state of repair. In particular, the Geneva-based Conference on Disarmament (CD) - the primary forum for multilateral disarmament negotiations-has been stalled for several years largely because of a disagreement between China and the United States. China demands that equal weight be given to negotiations on both a fissile material treaty and talks on preventing an arms race in outer space, while the United States wants the fissile material treaty to be the immediate priority, and argues that there is no arms race in outer space and no need for talks on that topic. As a result, the
$\mathrm{CD}$ has been unable to agree on a program of work that would allow it to begin the next round of disarmament discussions. ${ }^{59}$ In overall terms, as the 21 st century opens, there are few signs of clear progress toward the elimination of nuclear weapons.

\section{THE STRATEGY OF NULLIFICATION AND ITS CONSEQUENCES}

This situation troubles abolitionists, whose strategy depends heavily on progress in disarmament via international legal instruments, such as the proposed Nuclear Weapons Convention, which would sit alongside the Chemical Weapons Convention and the Biological Weapons Convention (BWC). ${ }^{60}$ But just as some groups and states rely almost solely on legal means and moral suasion to deal with nuclear proliferation problems - as the approach of New Zealand would suggest-others rely heavily on military countermeasures in an attempt to remove or cancel out threats generated by proliferation. ${ }^{61}$ For the purposes of this article, two dominant forms of this approach will be considered: preventive strikes, designed to remove an emerging or developed nuclear weapon (or other WMD) capability, and defenses erected to cancel out the threat such systems may pose. Both aim to nullify a nuclear weapons threat or potential threat through military means: hence they are part of what might be called the strategy of "nullification."

In terms of preventive actions, the 1981 Israeli attack on the Osirak complex in Iraq is a significant but rather unique example of a military attack designed to eliminate an emerging nuclear weapons threat. ${ }^{62}$ A more recent instance involving the same target country but in the midst of a broader armed conflict came during the 1990-1991 Gulf War, when conventional attacks on incipient Iraqi WMD capabilities were conducted as part of the overall military campaign. ${ }^{63}$ Of course, a nuclear strike might also be considered as the most extreme case of this type of nullification. The obstacles to this sort of action go way beyond concerns that with conventional strikes, the successful removal of the WMD capabilities in question is far from guaranteed. Even if successful in that limited sense, a nuclear strike would break the post-1945 nuclear use taboo against the use of nuclear weapons. ${ }^{64}$ That taboo is arguably an even more important international regime than nonproliferation itself. ${ }^{65}$ Such an attack might violate international law, cause huge losses for the target country, as well as grave damage to the international reputation of the country launching the strike. The latter would 
also need to bear in mind the prospect of retaliation against its own armed forces, its allies, and potentially its own homeland, which might take some unconventional yet quite catastrophic forms. In light of all of these potential costs, the Israeli action against Iraq some 20 years ago seems likely to prove exceptional.

In this context, it is not surprising that proposals for the construction of defenses against perceived nuclear weapons threats tend to dominate the nullification agenda, whose primary advocate is the United States. Such plans aim to provide non-nuclear protection against nuclear weapons launched by other states, and used in isolation would not violate the taboo against use of nuclear weapons. ${ }^{66}$ In and of themselves, such systems do not directly violate the global nonproliferation regime either. At least in these terms, the advantages of missile defense systems over preventive or preemptive strikes are quite clear.

Although missile defenses have quite a long history, by far the most memorable example is the Strategic Defense Initiative (SDI) launched by the Reagan administration in the early 1980s. This program sought a comprehensive defensive shield to protect the United States against Soviet ballistic missiles and the nuclear warheads they carried. For proponents of the management strategy (let alone the supporters of abolition), this ambitious project was a dangerous illusion. First, it threatened to undermine mutual vulnerability to nuclear retaliation, and thus increase incentives for striking first (reducing crisis stability). Second, it threatened to reignite the arms race, since ballistic missile defenses would encourage responses designed to overcome them (reducing arms race stability). On both counts, SDI was at loggerheads with the thinking enshrined in the 1972 Anti-Ballistic Missile Treaty, which had by then already become a cornerstone of superpower arms control.

The most optimistic variants of the SDI approach represented a very advanced case of the nullification strategy matching ambitious means to ambitious ends. The picture today is different. Both the envisioned technology and the objectives for which it is being sought are more selective. The missile defense coverage planned for East Asia and for the continental United States is not designed to deal with a massive failure in superpower nuclear deterrence. Current U.S. missile defense concepts are mainly a response to modern WMD threats posed by "rogue states" or the inadvertent launch of a small number of missiles by Russia. ${ }^{67}$
Moreover, at least until the end of the Clinton administration, the U.S. commitment to missile defense and the nullification strategy was open to question. The Clinton administration was concerned that the proliferation of both nuclear weapons and ballistic missiles was posing an increasing threat to the security of American forces abroad and to the continental United States. It signed TMD protocols with Japan. ${ }^{68}$ It also showed signs of an increasing willingness to study deployment options for a limited missile defense system for the continental United States, ${ }^{69}$ even though this was an especially distant and technically challenging prospect. ${ }^{70}$ But much of the motivation was a political desire to outflank and undercut Republican missile defense advocates on Capitol Hill. ${ }^{71}$ Moreover, in his last months in office, President Clinton announced a postponement of a widely anticipated decision about whether the United States would proceed with missile defense. On the whole, there were few signs during the Clinton administration of a wholehearted commitment to the nullification strategy. Even so, the active consideration of even limited missile defenses sufficed to generate a protracted diplomatic exchange with Russia and China, which all but overshadowed negotiations at the 2000 NPT Review Conference. While some reports had suggested that Russia was willing to contemplate amendments to the Anti-Ballistic Missile (ABM) Treaty, Moscow's main signal indicated that missile defense would undermine this cornerstone of its commitment to nuclear arms control and thus imperil the START process and other instruments. ${ }^{72}$ For its part, China indicated that it too regarded any NMD system as a potential threat to its own nuclear deterrence posture. ${ }^{73}$

International concerns that missile defense could thus imperil hopes for the international arms control agenda have only been heightened since George W. Bush became U.S. President. The new Bush administration has proposed a more ambitious scheme than its predecessor, the implementation of which is even more reliant on unproven technology. President Bush's high profile address on missile defense at the National Defense University in early May 2001 has underscored this commitment as the touchstone of the new administration's foreign policy. While President Bush spoke of the need for Russia and America to develop a new strategic framework, he made clear that this framework would "replace" and "leave behind the constraints of the ABM Treaty." 74 Subsequent congressional testimony by Deputy Defense Secretary Paul Wolfowitz indicated that the administration expects its 
missile defense research to violate the ABM Treaty in the near future, and that while the administration hopes to reach an agreement with Russia, it will not allow treaty commitments to circumscribe its missile defense plans. ${ }^{75}$ Other comments from the Bush administration have raised the prospect of U.S. withdrawal from the ABM Treaty "at a time," in President Bush's own words, which will be "convenient to America." "76

The new administration has succeeded in generating opposition to its missile defense plans from just about every quarter except for domestic supporters of the planned system and a handful of overseas allies. Of course, it was only to be expected that the reaction from Moscow and Beijing would be less than welcoming. ${ }^{77}$ It is also unsurprising that many strong supporters of global disarmament are worried about Washington's new missile defense proposals. The New Zealand government, for example, indicated its concern that the Bush plan "risks halting and reversing multilateral progress towards the elimination of nuclear weapons" and makes a new arms race more likely as "other weapons states will see missile defense [sic] as grounds for developing new generation weapons systems in response to it." 78 But the new missile defense proposals have also been unwelcome news for many proponents of the management strategy. For example, many European governments, often strong supporters of U.S. policies on security matters, are among the doubters in this category. ${ }^{79}$ French President Jacques Chirac reportedly told President Bush that U.S. missile defense plans would provide "a fantastic incentive to proliferate." $\$ 0$

\section{PROSPECTS FOR ACCOMMODATION}

At least in terms of a comparison between the U.S. and New Zealand positions, it might be argued that the search for international consensus on responding to nuclear proliferation is becoming increasingly challenging. On one hand, Helen Clark's Labor-Alliance coalition government (in power since November 1999) has done much to publicize the cause of nuclear abolition. On the other, however, President Bush has arrived at the White House with a commitment to placing a much stronger emphasis than his predecessor on missile defense. It would be absurd to suggest that along with the United States, New Zealand is responsible for shaping the international strategy on proliferation issues. But just as the U.S. position on these issues is crucial to their future development, New Zealand is one of the strongest small voices calling for international action. Such a two-way comparison also begs the question of to whether a new middle ground on nonproliferation needs to be, and can be, fashioned.

For the time being, the nullification strategy seems to have a certain amount of momentum in its favor. The Bush administration's missile defense plans (along with its skepticism towards formal arms control agreements such as the CTBT and efforts to strengthen the BWC) is certainly grabbing the headlines, although much of this attention is generated by the strong international reaction that this approach is triggering. In the wake of the terrorist attacks on the United States of September 11, 2001, missile defense opponents in the U.S. Congress appear to have retreated, giving the initiative to supporters of the nullification approach. ${ }^{81}$ Unlike both management and abolition, nullification does not need to rely on the endorsement of the international community and the grindingly slow pace of multilateral negotiations. In this way it rather suits a solitary superpower such as the United States, confident in its own ability to fix problems at its own pace rather than relying on international approval for negotiated measures that may not always be enforceable. ${ }^{82}$ Sanctions against identified prolif- erators can be turned on and off, positive incentives can be recalibrated or removed, and missile defense systems can conceivably be put in place even if they do not enjoy wide international approval. ${ }^{83}$

Yet the current climate that seems to favor nullification-at least in the United States-may not last. It is conceivable that as the international community comes to terms with twenty-first century proliferation challenges, a new middle ground could emerge with the management strategy once again playing a very significant role. This would not be unlike the transition that occurred in the early years of the Cold War. On the one hand there is a similarity between today's abolition strategies and the Baruch Plan. ${ }^{84}$ On the other hand there is a similarity between today's nullification strategies and the early Cold War plans for preventive strikes to forestall or eliminate the development of nuclear weapons capabilities by the Soviet Union. ${ }^{85}$

Neither of these earlier approaches to the world's first nuclear age was able to stand the test of time. By the late 1950s, Western strategic thinking was dominated by the quest to stabilize mutual deterrence rather than by attempts to somehow eliminate the nuclear problem. ${ }^{86}$ In other words, Western governments came to accept pragmatic managerial approaches rather than more radical solutions. It is quite conceivable that a similar pattern of gradual al- 
beit reluctant accommodation will occur today. ${ }^{87}$ If such accommodation occurs it will likely apply on a case-bycase basis. ${ }^{88}$ India, for example, is likely to be accepted by the international community as a legitimate possessor of nuclear weapons. ${ }^{89}$ By contrast, Iraq and North Korea, even though the "rogue state" label that the latter two have attracted is not without its problems-especially in relation to assumptions about their supposed irrationality—are not likely to enjoy such acceptance. ${ }^{90}$ But even carefully selected accommodation would upset the principles of the NPT by expanding the membership of the official nuclear club, setting a precedent that could unravel the nonproliferation regime even further. It would therefore need to be accompanied by a reformulation of the international arms control agenda where the members of this expanded grouping would need to commit themselves to new and binding responsibilities.

One possibility is for the NPT non-members-India, Pakistan and Israel - to stay outside that particular treaty, but be bound into the broader reaches of the overall nonproliferation regime, or at least to help cap capabilities at current levels, by signing up to the CTBT and the Fissile Material Cut-off Treaty. ${ }^{91}$ Such a result might be a better prospect than the current situation, but it might also perpetuate a complicating third category of states with the nuclear "haves" and the "have nots" being joined by the "not meant to haves." On the whole, it may be all too easy to undermine the existing principles of the old regime and extremely hard to generate new ones. The old system may be imperfect and far from leak proof, but it is better than the prospect of no system at all.

\section{MIXED STRATEGIES}

There is no point in denying that there are real strains being placed on the management strategy by nuclear proliferation itself, and also by the supporters of abolition and nullification. But it would be wrong for this article to suggest that these three strategies for dealing with proliferation are mutually exclusive or that their respective supporters are necessarily purists or extremists. Government policies and academic writings on the proliferation problem often reflect some sort of mix of two and sometimes three of these strategies. ${ }^{92}$ This situation mirrors the concept of mixed strategies in game theory, where in certain situations it is preferable to have a choice between alternative strategies, but different in that it does not utilize mixed strategies to enhance unpredictability in competitive relationships. ${ }^{93}$ Accordingly, proposals for the very gradual abolition of nuclear weapons on the one hand and for very minimal theatre defense systems on the other hand seem to reflect this non-purist approach. Either of these more moderate elements of abolition and nullification might conceivably be married to a strong commitment to the management strategy. ${ }^{94}$

The most significant point would be the weighting given to these three strategies in any particular mix and the changing effects the strategies have on each other when differing weightings are adopted. ${ }^{95}$ It might be argued that the most productive mix would place the main emphasis is on management. The dominance of this middle-ground strategy would seem to allow limited support for moves to disarm, when this is possible, and limited support for nullification strategies, when these are necessary. ${ }^{96}$ But the bedrock of this particular mixed approach would rest on stabilizing arms control measures. This mix would create a positive sum game between the three strategies: they could be mutually supportive instead of operating at the expense of each other. ${ }^{97}$

The same logic does not seem to hold for mixed strategies dominated by either abolition or nullification. In these cases a zero-sum situation may be more likely where positions become polarized rather than coordinated, and where any middle ground is increasingly undermined. For example, proponents of speedy abolition may overlook the political and security rationales that make nuclear weapons attractive bargaining tools for otherwise isolated and poor states (as well as for the NWS themselves). ${ }^{98}$ Some abolitionists thus adopt a position around which a truly international consensus may be very difficult to establish (assuming of course that such consensus matters). Likewise, the idea of nullification through unilateral military measures, if pushed too hard, places enormous pressure on an already strained arms control agenda, and may rule out even token progress towards elimination.

But such qualifications presume that it is the management strategy that can best achieve international consensus and action in dealing with proliferation. There is another mixed approach which takes a quite different track and emphasizes the common ground between the strategies of abolition and nullification: to at least some degree, both of these aim to eliminate (and not just cope with) the dangers associated with nuclear weapons. One would do so globally through complete disarmament, the other on a case-by-case basis through military countermeasures. Rather than two ends of a spectrum (with the management strategy occupying the mid-point), parts of the abo- 
lition and nullification strategies might be compared (if rather unkindly) to the political extremes of communism and fascism that, according to the old categorization of them as different forms of totalitarianism, are closer to each other than they are to liberal democracy. ${ }^{99}$

In this light, Ronald Reagan's famous (or infamous) offer to end the nuclear menace by sharing SDI technology with the Soviet Union may have had more in common with the disarmament aims of the peace movement than some cynics would like to believe. ${ }^{100}$ Reagan's 1983 call for nuclear weapons to be made "impotent and obsolete" would seem to make a fairly good bumper sticker for abolitionists. ${ }^{101}$ On less ambitious, but rather similar lines President George W. Bush now proposes that a strong missile defense system should be coupled with deep cuts in the U.S. nuclear arsenal. Since assuming office, Bush has delivered on his main promise to give missile defense greater priority. His administration has also, however, taken some steps to reduce the U.S. nuclear arsenal, proposing in its FY2002 defense budget, for example, that the $50 \mathrm{MX}$ intercontinental ballistic missiles in the U.S. strategic force be retired. ${ }^{102}$

Hence, even if they oppose missile defense itself, disarmament advocates would welcome any signs that the world's leading power may be considering further slimming a stockpile that has already come down since the end of the Cold War. The way in which such cuts might be achieved, however, may not match the standard international legal instruments favored by many abolitionists. The Bush Administration has indicated a general aversion to formal arms control agreements, be they multilateral or bilateral. Indeed, there may even be the possibility of unilateral action by the United States reducing its nuclear arsenal quite independently of Russian levels and intentions. Despite their unilateral character, however, should such moves help trigger a new round of reductions by some of the other NWS; the abolitionist cause may have been helped in a potentially significant fashion.

There may be even more promise for a nullificationabolition mixed strategy in the Bush administration's doubts over how much security the balance of terroroften termed mutual assured destruction-provides. The key question here, however, is whether advocates of missile defense want to replace mutual deterrence with a very new philosophy (one that includes elements of abolition) or whether the demand is simply for a supplementation of the Cold War strategy of nuclear deterrence. Statements from key figures in the new Administration indicate that the latter may win out. For example, in his confirmation hearings, Secretary of Defense Donald Rumsfeld explained that the role of missile defense was to "strengthen deterrence and provide an important complement purely to retaliatory capabilities." 103

Moreover, even if certain political figures were convinced that the balance of terror needed to be replaced rather than "complemented," there would be more than a few officials ready to point out the pitfalls. President Bush himself has argued that, at least for now, nuclear weapons continue to be vital to U.S. national security. Indeed skeptics might wonder if the Bush admini- stration's questioning of the orthodox deterrence strategy is primarily aimed at undercutting Russian arguments that the ABM Treaty is somehow sacrosanct (based as it is on preserving the very same balance of terror). The Bush administration arguments about deterrence might seek mainly to pave the way for a new bargain on missile defense, the ultimate objective. Philip Gordon has noted, for example, that there seems to be at least some enthusiasm in Moscow for the idea of "trading off deeper cuts in nuclear missiles for the deployment of defensive systems." 104 Yet even if current U.S. willingness to discount the value of mutual assured destruction is a tactic in a bigger game, there is still reason to consider the possibility of a pairing between nullification and abolition. To adapt a Wilsonian formula from the Great War, a combination of the two strategies may produce a conceivable situation where missile defense makes the world safe for disarmament.

Such a formula could conceivably have both short term and long-term applications. In the short term, NWS who are insured against the threat of small-scale, rogue or inadvertent nuclear attacks might be able to concentrate on dealing with the Cold War legacy of large nuclear arsenals designed to deter a massive nuclear exchange. And if threshold states could get access to this sort of small-scale protection, their justifications for going nuclear in the first place might also be addressed (in the sense that they might have less to fear from the nuclear programs of neighboring countries). The long-term applications might cover the critical final phases of abolition when each nuclear weapon state retains only a very few warheads. In such a situation, (however unlikely it may be that the world would get there in the first place) missile defense could provide the assurance some NWS need against their concerns that the others may be cheating on their end of the disarmament bargain. 
These propositions are of course hypothetical. Moreover, for missile defense to help make the world safe for nuclear disarmament, it would probably need to be available on a global basis, not just to specially selected allies of the United States. How Washington might share this technology in an age of unilateral foreign policy is difficult to envisage. On one hand, it would be reluctant to sign the technology over to an international authority for global benefit (a kind of Baruch Plan for missile defense). On the other, for traditional competitors (especially Russia and China) to accept direct missile defense assistance from Washington might smack of the American hegemony that Beijing, in particular, is so keen to avoid.

Even so, a fusing of nullification and missile defense at the expense of the middle ground management strategy is at least a conceivable option for mixed strategies. Here the abolitionists would be distancing themselves formal arms control as a means to their end, on the basis that it often justifies the status quo of nuclear deterrence. For example, it is perhaps ironic that in its quest for international progress towards complete nuclear disarmament at the 2000 NPT Review Conference, New Zealand accepted the argument that any future steps should promote "international stability." 105 Some states will undoubtedly interpret this language to mean the stability of nuclear deterrence. ${ }^{106}$ Following the conference, New Zealand Disarmament Minister Matt Robson acknowledged: "There was a need for the non-nuclear weapon states like us, and the nuclear weapon states to adjust their demands so that a package of realizable steps could be agreed." ${ }^{107}$ But perhaps multilateral nuclear arms control involves too many such compromises for it to be a serious tool for real disarmament.

Indeed one danger in a knee jerk rejection of missile defense by the disarmament community is that it paints abolitionists into the corner occupied by China and Russia, who oppose missile defense because they wish to preserve the utility of nuclear deterrence within their own national security strategies. Russia and China have a rather different approach from the Bush administration, which evidently believes that missile defense can be used to supplement traditional nuclear deterrence, reduce the incentive for proliferation, and trigger further nuclear force reductions. ${ }^{108}$ But while President Bush's call for "new concepts of deterrence that rely on both offensive and defensive forces" certainly suggests Washington's willingness to integrate its own missile defense program within a revised deterrence framework, it is unlikely that the same
American system will be compatible with the deterrence posture of these other two states. ${ }^{109}$ Once again, missile defense would seem to have a much greater chance of producing positive results, including in its role of prompting further cuts in nuclear forces, if available as a global, cooperative system.

Any marriage between abolition and nullification would also involve dependable commitments on the part of the supporters of missile defense. Few of the strongest advocates of nullification need to be convinced of the limitations of the management strategy: the Bush administration's skeptical approach to multilateral diplomacy (including arms control treaties) seems to give weight to this argument. But could the abolitionists trust the missile defenders to achieve nuclear reductions below minimal deterrence levels? Would the balance shift increasingly from combining missile defense with deep cuts to missile defense existing simply as a supplement to a robust nuclear deterrence posture?

Indeed, in January 2001, a U.S. study group, some of whose members have subsequently joined the Bush administration, argued that while substantial nuclear weapons reductions cannot be ruled out, "nuclear deterrence may become even more important in the future than it has been in the past." 110 Likewise, the Bush administration may desire the flexibility to raise, as well as lower, U.S. nuclear weapons capabilities should the environment dictate it. This position is incompatible with abolition. Another potential incompatibility is suggested by reports that the Bush administration may not object to a Chinese missile build-up as a way of addressing Beijing's concerns about missile defense. ${ }^{111}$

There is also the intriguing question of what specific measures such an alliance would rely on, especially if both the disarmers and missile defenders (for somewhat different reasons) had concluded that the formal, treaty-based measures of multilateral arms control needed to be replaced by more effective approaches. Michael Krepon has noted that in the range of cooperative threat reduction measures adopted by Russia and the United States since the end of the Cold War, less formal measures have tended to be more productive than formal treaties. ${ }^{12}$ Other authorities have suggested that there is a range of additional reciprocal measures that are not treaty-based waiting in the wings. ${ }^{113}$ There are also prominent calls in the United States for "a restructured approach to arms control," which "need not foreclose the prospect of parallel nuclear re- 
ductions, if judged appropriate following a serious U.S. strategic review." 114

Yet there are serious question marks over the idea of concerted unilateral disarmament measures among the NWS. As a point of principle, would the enthusiasm for bypassing formal arms control arrangements be seen outside the United States with anything more than a mixture of cynicism and despair? Would abolition really become possible as the cumulative effect of a whole series of bilateral deals between the NWS, perhaps with missile defense systems as part of the transition arrangement? Or would the best that could be hoped for under these arrangements be reductions to minimal deterrence levels: a sort of NWS modus vivendi that produces results somewhere in between the achievements of the START process and the much more radical ambitions of a global nuclear weapons convention? Moreover, would the introduction of missile defense really render obsolete the very long-standing arguments about the instability that might come with total disarmament? ${ }^{115}$ And would missile defense be available to anyone other than the most wealthy NWS? The answers to these questions may be as elusive as an operational missile defense system itself.

\section{THE OUTLOOK}

The challenges associated with nuclear proliferation look set to persist well into the 21 st century. Nuclear weapons are clearly still appealing to some states for a range of reasons, including the search for both prestige and security. They also seem to be ideal candidates for producing the dangerous cycles of interacting expectations and behavior that may feature even in a post-Cold War international environment. ${ }^{116}$ In the case of the United States, where so much of the concern about nuclear proliferation is centered, these issues remain pertinent because of their obvious intercontinental potential. They thereby pose at least a conceivable threat to affluent states, even in periods when the risk of entanglement in major interstate conflict is low. ${ }^{117}$ This point helps explain the popularity of missile defense systems even among U.S. political leaders who are skeptical about aspects of wider international engagement. Moreover, as one of the essential prerequisites for great power status during the last fifty years, nuclear weapons - and responses to them such as missile defense systems-will remain integral to the overall relationships between the world's leading states.

Nuclear proliferation is also an easy focus of attention for other reasons. One of these is the relative ease with which nuclear weapons and missiles can be counted and their future growth extrapolated in the linear fashion that produces exciting treatment in threat assessments. This apparently quantifiable threat can be contrasted with the difficulty of measuring and assessing the messy civil and interethnic conflicts that are such a part of contemporary international affairs. Institutional factors also play a role in the prominence of nuclear proliferation, thanks largely to the Cold War, which prompted the training of a large body of analysts trained and ready to analyze the next instance of proliferation, wherever or however it may occur.

In short, nuclear weapons issues retain an urgency that makes them stand out alongside other features of the international security environment. But the prominence of the nuclear proliferation issue does not mean that it will be easy for the supporters of multilateral arms control to keep their own business at the top of the international affairs agenda. The difficulties in pursuing the management strategy in an era when some states have bucked the nonproliferation regime, and when Washington is beefing up its missile defense plans, will remain difficult to resolve. Certainly a stalled management strategy coupled by a sense of an implacable contest between the advocates of abolition and nullification will not make a happy mix.

But the idea that the disarmers and the missile defenders might be able to work together on some of their common goals deserves further study. To examine this question seriously might require a shift away from current thinking about the effects - both positive and negative - that U.S. missile defense plans will have for the abolitionist agenda toward emphasizing the potential convergence between an internationally shared missile defense system and hopes for global nuclear disarmament. Such cooperation might well favor the less worn paths of concerted unilateral reductions in nuclear arsenals over the traditional machinery of multilateral negotiation. This trend, in turn, would pose even more questions for the future of the middle ground, management approach. 
${ }^{1}$ The author would like to thank Gary Schaub Jr., Anthony L. Smith and Guy Wilson-Roberts for their comments on an earlier version of this article, and two anonymous reviewers for their helpful additional suggestions. Responsibility for any errors or omissions rests with the author alone.

${ }^{2}$ Even though the new Bush Administration has stopped making the distinction between NMD and TMD, this article persists with the earlier terminology in some cases because of the importance of that distinction in earlier debates and policy decisions.

${ }^{3}$ The White House, A National Security Strategy for a New Century (Washington DC: U.S. Government Printing Office, October 1998), p. 4. On the sources of "proliferation alarm" in the United States, see Gilles Andréani, "The Disarray of U.S. Nonproliferation Policy," Survival 41 (Winter 1999-2000), pp. 43-8. ${ }^{4}$ National Intelligence Council, Global Trends 2015: A Dialogue About the Future with Nongovernment Experts, NIC 2000-02, December 2000, p. 38, <http://www.cia.gov/cia/publications/globaltrends2015/index.html>.

${ }^{5}$ In the mid-1960s Morton Halperin observed: "There seems to be little doubt in most people's minds that the fewer the number of nuclear powers the better." Morton Halperin, "A Ban on the Proliferation of Nuclear Weapons," in Evan Luard, ed., First Steps to Disarmament: A New Approach to the Problems of Arms Reductions (London: Thames \& Hudson, 1965), p. 139. For a prominent counter-argument, see Kenneth N. Waltz, "More May Be Better," in Scott D. Sagan and Kenneth N. Waltz, The Spread of Nuclear Weapons: A Debate (New York: Norton, 1995), pp. 1-45.

${ }^{6}$ For a useful overview of these concerns, see Wyn Bowen, "Shield Against Rogues," The World Today 56 (January 2000), pp. 4-6.

${ }^{7}$ See Ashton Carter, John Deutch and Philip Zelikow, "Catastrophic Terrorism: Tackling the New Danger," Foreign Affairs 77 (November/December 1998), pp. 80-94; Walter Laqueur, "The New Face of Terrorism," Washington Quarterly 21 (Autumn 1998), pp. 169-178. For the argument that such threats have been overrated, see John Mueller and Karl Mueller, "Sanctions of Mass Destruction," Foreign Affairs 78 (May/June 1999), pp. 45-48.

${ }^{8}$ See Ronald E. Powaski, "Russia: The Nuclear Menace Within," Current History 98 (October 1999), pp. 341-3; Christopher Bluth, The Nuclear Challenge: US-Russian Strategic Relations after the Cold War (Aldershot, U.K.: Ashgate, 2000), pp. 155-169.

${ }^{9}$ See François Heisbourg, "The Prospects for Nuclear Stability Between India and Pakistan," Survival 40 (Winter 1998-99), pp. 85-6; Devin T. Hagerty, "South Asia's Big Bangs: Causes, Consequences, and Prospects," Australian Journal of International Affairs, 53 (April 1999), p. 25; Robert F. Mozley, The Politics and Technology of Nuclear Proliferation (Seattle: University of Washington Press, 1998), pp. 11-13. On this problem in the traditional context of the U.S. and Russian nuclear arsenals, see Bruce Blair, The Logic of Accidental Nuclear War (Washington, DC: The Brookings Institution, 1993); Scott D. Sagan, The Limits of Safety: Organizations, Accidents, and Nuclear Weapons (Princeton: Princeton University Press, 1993).

${ }^{10}$ See Rodney W. Jones, Mark G. McDonough et al., Tracking Nuclear Proliferation: A Guide in Maps and Charts, 1998 (Washington DC: The Carnegie Endowment for International Peace, 1998), p. 6.

${ }^{11}$ See Joseph Cirincione, "The Asian Nuclear Reaction Chain," Foreign Policy 118 (Spring 2000), pp. 127-9.

${ }^{12}$ See Randall Forsberg et al., Nonproliferation Primer: Preventing the Spread of Nuclear, Chemical, and Biological Weapons (Cambridge, MA and London London: MIT Press, 1995), pp. 19-20. On South Asia see "Might and Menace," Far Eastern Economic Review, June 4, 1998, pp. 27-9; "The Race is On," Far Eastern Economic Review, June 11, 1998, pp. 20-22. On North Asia, see Kent Calder "The New Face of Northeast Asia," Foreign Affairs 80 (January/February 2001), pp. 114-5.

13 These concerns were highlighted most notably in the 1998 report of the Rumsfeld Commission to the U.S. Congress. For an unclassified version, see U.S. Congress, "Executive Summary of the Report of the Commission to Assess the Ballistic Missile Threat to the United States," July 15, 1998, < http:// www.fas.org/irp/threat/bm-threat.htm>. For commentary from a member of the Commission see Richard L. Garwin, "What We Did," Bulletin of the Atomic Scientists 54 (November/December 1998), pp. 40-46.

${ }^{14}$ See Forsberg et al., Nonproliferation Primer, p. 20.

15 The earlier nuclear weapons ambitions of India and Pakistan, including India's first test in 1974, are discussed briefly in Toby F. Dalton, "Toward
Nuclear Rollback in South Asia," Current History 97 (December 1998), pp. 413-4.

${ }^{16}$ See "Fire, Backfire: Missile Test Threatens Overtures to Pyongyang," Far Eastern Economic Review, September 10, 1998, p. 22; "North Korea's Missile Development Changes Japan's View on Military," International Herald Tribune, August 3, 1999.

${ }^{17}$ See International Institute for Strategic Studies, The Military Balance, 1999-2000 (Oxford: Oxford University Press, 1999), pp. 171-2; Paul H.B. Godwin, "China's Nuclear Forces: An Assessment," Current History 98(September 1999), pp. 260-5.

${ }^{18}$ See Rebecca Johnson and Daryl Kimball, "Who Needs the Nuclear Test Ban?” Disarmament Diplomacy 59 (August 2001), <http://www.acronym. org.uk/dd/dd59/59ctbt.htm>.

${ }^{19}$ For a declassified version, see [Report of] The United States House of Representatives Select Committee on U.S. National Security and Military/ Commercial Concerns with the People's Republic of China at <http:// www.house.gov/coxreport>.

${ }^{20}$ See Bowen, "Shield Against Rogues," p. 6.

${ }^{21}$ See Michael McDevitt, "Beijing's Bind," Washington Quarterly 23 (Summer 2000), pp. 178-180.

${ }^{22}$ For the argument that "the most complex nuclear issues are located in Asia and nowhere else," see Thérèse Delpech, "Nuclear Weapons and the 'New World Order': Early Warning from Asia?” Survival 40 (Winter 1998-99), p. 58. For a brief and very helpful discussion of WMD issues in the Asia-Pacific region, see Tim Huxley and Susan Willett, Arming East Asia, IISS Adelphi Paper 329 (Oxford: Oxford University Press, 1999) pp. 72-75.

${ }^{23}$ Australian Department of Defense, Australia's Strategic Policy (Canberra: Australian Department of Defense, 1997), p. 31. For Jeanne Kirkpatrick's warnings to Australia on nuclear proliferation and WMD issues, see "Australia 'needs missile defense'," Dominion (Wellington), October 13, 1998, p. 4. On similar warnings given by retired U.S. Army General Donn Starry at a conference held in Brisbane, see "Smart Army on Parade," The Australian, October 21,1998 , p. 7.

${ }^{24}$ See Philip Towle, Enforced Disarmament from the Napoleonic Campaigns to the Gulf War (Oxford: Oxford University Press, 1997), pp. 188-196.

${ }^{25}$ See International Institute for Strategic Studies, Strate gic Survey 1998/99 (Oxford: Oxford University Press, May 1999), pp. 168-176; Marc Weller, "The US, Iraq and the Use of Force in a Multipolar World," Survival 41 (Winter 1999-2000), pp. 82-7.

${ }^{26}$ Bowen, "Shield Against Rogues," p. 5. These concerns are also discussed in Geoffrey Kemp, "Iran: Can the United States Do a Deal?" Washington Quarterly 24 (Winter 2001), p. 116. See also: Office of the Secretary of Defense, Proliferation Threat and Response (Washington, DC: U.S. Government Printing Office, January, 2001).

${ }^{27}$ See Delpech, "Nuclear Weapons," pp. 60-1.

${ }^{28}$ On Iran's concerns about Israel and Iraq's capabilities in this context, see Michael Eisenstadt, “Living with a Nuclear Iran?” Survival 41 (Autumn 1999), pp. 126-129.

${ }^{29}$ See National Intelligence Council, Global Trends 2015, p. 34. On Russia's 1997 abandonment of its nuclear no first-use pledge, see Powaski, "Russia: The Nuclear Menace," p. 341.

${ }^{30}$ Viktor Chernomyrdin, "Impossible to Talk Peace with Bombs Falling," Washington Post, May 27, 1999, p. A39. START II was ratified by the Russian parliament in 2000, but conditions were attached that have so far prevented the treaty from entering into force. Nevertheless, the Russian inventory of operational weapons continues to diminish.

${ }^{31}$ See "New Russian Security Plan Criticizes West: Doctrine Broadens Nuclear Use Policy," Washington Post, January 15, 2000, p. A1; and Nikolai Sokov, "Russia's New National Security Concept: The Nuclear Angle," Monterey Institute of International Studies, Center for Nonproliferation Studies Web Report, January 2000, <http://cns.miis.edu/pubs/reports/sokov2.htm>.

${ }^{32}$ This mixed picture since the end of the Cold War is outlined in Robert Ayson, "New Zealand and Global Nuclear Disarmament: Is the Glass Half-Full of Half-Empty?" in Rouben Azizian, ed., Nuclear Developments in South Asia and the Future of Global Arms Control (Wellington: Centre for Strategic Studies in association with Department of Political Studies, University of Auckland, 2001), pp. 297-8. 
${ }^{33}$ See Jones and McDonough et al., Tracking Nuclear Proliferation, pp. 3-4; 71-100; 223-250; Bluth, The Nuclear Challenge, pp. 71-99.

${ }^{34}$ For UN Secretary General Kofi Annan's frustrations on this score, see "US Singled Out in New Arms Race Fear," Dominion (Wellington), February 4, 2000, p. 4.

${ }^{35}$ For a notable exception, see Albert Wohlstetter, "Nuclear Sharing: NATO and the N+1 Country," Foreign Affairs 39 (April 1961).

${ }^{36}$ See Brad Roberts, "Rethinking N+1," National Interest 51 (Spring 1998), pp. 75-80.

${ }^{37}$ See Joseph Cirincione, "Nuclear Free-Fall," Washington Quarterly 22(Winter 1999), p. 19; Bruce Blair, "Impact of NMD on Russia, Nuclear Security," in Center for Defense Information (CDI), National Missile Defense: What Does is All Mean? A CDI Issue Brief (Washington DC: CDI, September 2000), pp. 20-22.

${ }^{38}$ See for example Brahma Chellaney, "After the Tests: India's Options," Survival 40 (Winter 1998-9), pp. 105-8; Sandy Gordon, "Can the South Asian Nuclear Equation Balance?" Asia-Pacific Defense Reporter 24 (October/November 1998), pp. 6-7.

${ }^{39}$ For some classical examples from the early 1960s, see Thomas C. Schelling and Morton H. Halperin, Strategy and Arms Control (New York: Twentieth Century Fund, 1961); Hedley Bull, The Control of the Arms Race: Disarmament and Arms Control in the Missile Age (London: Weidenfeld \& Nicolson, 1961); Donald G. Brennan, ed., Arms Control, Disarmament and National Security (New York: George Braziller, 1961).

${ }^{40}$ Schelling and Halperin, Strategy and Arms Control, p. 2.

${ }^{41}$ Joseph Cirincione, "Historical Overview and Introduction," in Joseph Cirincione, ed., Repairing the Regime: Preventing the Spread of Weapons of Mass Destruction (London: Routledge, 2000), p. 4.

${ }^{42}$ See Lawrence Freedman, The Evolution of Nuclear Strategy, $2^{\text {nd }}$ ed. (Basingstoke: Macmillan, 1989), pp. 313-329.

${ }^{43}$ For the argument that U.S. extended deterrence commitments continues to reduce proliferation tendencies among NATO countries, see David S. Yost, The U.S. and Nuclear Deterrence in Europe, IISS Adelphi Paper 326 (Oxford: Oxford University Press, 1999), pp. 25-27.

${ }^{44}$ Bruno Tertrais, Nuclear Policies in Europe, IISS Adelphi Paper 327 (Oxford: Oxford University Press, 1999), p. 7.

${ }^{45}$ See, for example, Keith B. Payne, Deterrence in the Second Nuclear Age (Lexington: University Press of Kentucky, 1996); Michèle A. Flournoy, "Implications for U.S. Military Strategy," in Robert D. Blackwill \& Albert Carnesale, eds., New Nuclear Nations: Consequences for U.S. Policy (New York: Council on Foreign Relations Press, 1993), pp. 141-147. For the proposition that nuclear deterrence was neither stable nor effective during the Cold War, see Richard Ned Lebow and Janice Gross Stein, We All Lost the Cold War (Princeton: Princeton University Press, 1994).

${ }^{46}$ See "Who Will Curb the Rogue States Now," Guardian (Manchester), October 15, 1999, p. 15. For a defense of the NPT in this context by the UN Under-Secretary General for Disarmament Affairs, see Jayantha Dhanapala, "The NPT Regime: External and Internal Challenges," paper delivered to Seventh Carnegie International Nonproliferation Conference, Carnegie Endowment for International Peace, Washington DC, January 11, 1999, p. 2.

${ }^{47}$ For a brief assessment, see Paulo Wrobel, "Testing Times," The World Today 55 (November 1999), pp. 6-7.

${ }^{48}$ For an earlier treatment of the dual options, see Lawrence Freedman, Arms Control: Management or Reform? Chatham House Papers 31 (London: Routledge and Kegan Paul, 1986).

${ }^{49}$ For a brief description of the Baruch Plan, see Mozley, The Politics and Technology, pp. 244-7.

${ }^{50}$ Treaty on the Nonproliferation of Nuclear Weapons, Article VI, in Coit D. Blacker and Gloria Duffy (eds.), International Arms Control: Issues and Agreements, 2d ed. (Stanford: Stanford University Press, 1994), p. 395.

${ }^{51}$ See International Court of Justice, "Legality of the Threat or Use of Nuclear Weapons," Advisory Opinion, July 8, 1996, at <www.icj-cij.org/icjwww/ idecisions/isummaries/iunanaummary960708.htm>. New Zealand's role in the World Court Project is discussed in Roderic Alley, The Domestic Politics of International Relations: Cases from Australia, New Zealand and Oceania (Aldershot, U.K.: Ashgate, 2000), pp. 23-51. The Non-Aligned Movement's enthusiasm for seeking a World Court ruling is noted in Jaswant Singh, "Against
Nuclear Apartheid," Foreign Affairs 77 (September/October 1998), p. 50.

${ }^{52}$ For a highly readable guide to the range of abolitionist opinion, see Jonathan Schell, The Gift of Time: The Case for Abolishing Nuclear Weapons Now (New York: Henry Holt, 1998).

${ }^{53}$ Once that deadline had passed, Abolition 2000 removed the specific time requirement from their statement. See Abolition 2000, Abolition 2000 Statement, at <http://www.napf.org/abolition2000/ablstate.html>.

${ }^{54}$ For a significant U.S. call for eventual prohibition, see National Academy of Sciences, Committee on International Security and Arms Control, The Future of U.S. Nuclear Weapons Policy (Washington: National Academy Press, 1997). Also see Ramesh Thakur, "Time for a Nuclear-Weapon-Free World," New Zealand International Review 22 (January/February 1997), pp. 21-27.

${ }^{55}$ See Marianne Hanson and Carl Ungerer, "The Canberra Commission: Paths Followed, Paths Ahead," Australian Journal of International Affairs 53 (April 1999), pp. 5-17.

${ }^{56}$ Ibid., pp. 13-14.

${ }^{57}$ On New Zealand's role at the 2000 Review Conference and in nuclear disarmament in general, see Robert Ayson, "Towards a Nuclear Weapons Free World? New Zealand and the Quest for Global Nuclear Disarmament," International Journal 55 (Autumn 2000), pp. 531-544. The "unequivocal undertaking by the nuclear-weapon States to accomplish the total elimination of their nuclear arsenals leading to nuclear disarmament" is contained in Final Document of the Review Conference of the Parties of to the Treaty on the Nonproliferation of Nuclear Weapons, NPT/CONF.2000/28, Volume 1, Part 1, p. 14.

${ }^{58}$ For the UN Disarmament Affairs Under-Secretary General's address to that conference, see Jayantha Dhanapala, "Opening Address to Ka hao te rangatahi: A Pacific Way to Disarmament," UN Regional Meeting in Asia and the Pacific, UN Regional Center for Peace and Disarmament in Asia and the Pacific, Wellington, New Zealand, March 27, 2001 at <http://www.un.org/Depts/dda/ speech/27mar2001.htm>.

${ }^{59}$ See Jenni Rissanen, "The Search for a Work Program: The CD Fighting a Losing Battle?” Disarmament Diplomacy 54 (February 2001), pp. 25-35.

${ }^{60}$ See International Association of Lawyers Against Nuclear Arms et al., Security and Survival: The Case for a Nuclear Weapons Convention (Cambridge MA: IPPNW, 1999).

${ }^{61}$ See New Zealand Ministry of Foreign Affairs and Trade, Disarmament and Arms Control, Information Bulletin 62 (Wellington: Ministry of Foreign Affairs and Trade, June 2000).

${ }^{62}$ See Philip Zelikow, "Offensive Military Operations," in Blackwill and Carnesale, eds., New Nuclear Nations, pp. 167-168.

${ }^{63} \mathrm{Ibid} .$, p. 170. On the two Iraq cases as examples of preventive military action, see Steve Fetter, "Ballistic Missiles and Weapons of Mass Destruction: What Should Be Done," in Robert J. Art \& Kenneth N. Waltz, eds., The Use of Force: Military Power and International Politics (Lanham MD: University Press of America, 1993), p. 565.

${ }^{64}$ See Thomas C. Schelling, Arms and Influence (New Haven: Yale University Press, 1966), pp. 114-116.

${ }^{65}$ For the counter-argument that the taboo idea is overrated, see Colin S. Gray, The Second Nuclear Age (Boulder, CO: Lynne Rienner Publishers, 1999), pp. 103-108.

${ }^{66}$ In extreme circumstances, target countries could fear that missile defenses might provide the United States with cover to employ preemptive nuclear strikes without fear of effective retaliation.

${ }^{67}$ See Michael Krepon, "Missile Defense: Not Such a Bad Idea," Bulletin of the Atomic Scientists 55 (May/June 1999), pp. 31-3.

${ }^{68}$ See "U.S. and Japan to Join in Missile Defense to Meet Pyongyang Threat," International Herald Tribune, July 29, 1999.

${ }^{69}$ See "Cohen Says U.S. Will Build Missile Defense: Weapon to Be Pursued Despite '72 ABM Treaty," Washington Post, January 21, 1999, pp. A1, A10. For a brief description of the NMD system proposed by the Clinton administration, see International Institute for Strategic Studie $s$, "US Missile Defense: How Much is Enough?" Strategic Comments 5 (December 1999), p. 1.

${ }^{70}$ See "Missile Fails in Setback for U.S. Defense Plan," International Herald Tribune, January 20, 2000.

${ }^{71}$ As noted in Michael O'Hanlon, "Star Wars Strikes Back," Foreign Affairs 78 (November/December 1999), p. 78.

${ }^{72}$ See Powaski, "Russia: The Nuclear Menace," pp. 343-4.

${ }^{73}$ Regarding Chinese concerns, see Brad Roberts, Robert A. Manning, and 
Ronald N. Montapero, "China: The Forgotten Nuclear Power," Foreign Affairs 79 (July/August 2000), pp. 53-63.

${ }^{74}$ Remarks by President George W. Bush to Students and Faculty at National Defense University, May 1, 2001, Fort Lesley J. McNair, Washington DC, at <http://www.whitehouse.gov/news/releases/2001/05/20010501-10.html>.

${ }^{75}$ U.S. Senate, Armed Services Committee, Prepared Testimony of Deputy Secretary of Defense Paul D. Wolfowitz before the Senate Armed Services Committee, July 12, 2001, at <http://www.senate.gov/ armed_services/ statemnt/2001/010712wolf.pdf $>$.

${ }^{76}$ Quoted in "Bush Flatly Says U.S. Will Pull Out of Missile Treaty," New York Times, August 24, 2001, <http://www.nytimes.com>.

${ }^{77}$ See "Jiang and Putin Line Up Against U.S. Missile Plan," International Herald Tribune, June 15, 2001, at <http://www.iht.com>; "Russia Bars Joining U.S. in Quitting ABM Treaty," International Herald Tribune, August 23, 2001, <http://www.iht.com>.

${ }^{78}$ New Zealand Ministry of Disarmament, Press Release, May 2, 2001, "Honorable Phil Goff, New Zealand Minister of Foreign Affairs and Trade and Honorable Matt Robson, New Zealand Minister for Disarmament Express New Zealand Concern Over U.S. Missile Defense Plans."

${ }^{79}$ See Phillip H. Gordon, "Bush, Missile Defense and the Atlantic Alliance," Survival 43 (Spring 2001), pp. 16-33.

80 "Bush Tells NATO Shield is Needed," International Herald Tribune, June 14, 2001, <http://www.iht.com>.

${ }^{81}$ Adam Clymer, "Shield Plan Appears Buoyed by a New Bipartisan Mood," New York Times, September 14, 2001, <http://www.nytimes.com>.

${ }^{82}$ During the Cold War, the international arms control process was closer to a two-player game, automatically giving the United States one of the principal roles. Today, progress in this arena seems more dependent on a wider range of players. This change does not preclude a coordination of these differing positions, but such a process will take time.

${ }^{83}$ This sense is relayed in the British headline "Bush Team Longs to Go It Alone," Guardian Weekly (Manchester) May 24-30, 2001, p. 6.

${ }^{84}$ This parallel is noted in Schell, The Gift of Time, pp. 7-8.

${ }^{85} \mathrm{On}$ this preventive thinking, see Marc Trachtenberg, History and Strategy (Princeton: Princeton University Press, 1991), pp. 103-7.

${ }^{86}$ See Freedman, Evolution, pp. 190-210. On Washington's consideration but eventual rejection of the idea of preventive strikes against China's emerging nuclear weapons capabilities in the early 1960s, see William Burr and Jeffrey T. Richelsen, "Whether to 'Strangle the Baby in the Cradle': The United States and the Chinese Nuclear Program," International Security 25 (Winter 2000/ 01), pp. 54-99.

${ }^{87}$ The contemporary prevalence of approaches that seek to manage rather than transform is noted in Andrew Butfoy, "Is Arms Control Approaching a Dead End?" Australian Journal of International Affairs 52 (November 1998), p. 305. On the moderation of Washington's initially firm stance towards India and Pakistan, see Andréani, "The Disarray," pp. 53-4; "U.S. India Talks Gain and Could Lead to Easing of Sanctions," New York Times, February 2, 1999, p. A9. On what other countries can do to help India and Pakistan, see Heisbourg, "The Prospects for Nuclear Stability," pp. 86-90.

${ }^{88}$ This may be another sign of the multi-player issue noted above.

${ }^{89}$ On this theme, see Mohammed Ayoub, "India Matters," The Washington Quarterly 23 (Winter 2000), p. 34.

${ }^{90}$ For an interesting critique of the exaggerated irrationality argument, see Hazel Smith, "Bad, Mad, Sad or Rational Actor? Why the 'Securitization' Paradigm Makes for Poor Policy Analysis of North Korea," International Affairs 76 (January 2000), pp. 111-132. On North Korean motives for acquiring missiles to deter U.S. involvement in a conflict on the Korean peninsula, see Selig Harrison, "The Missiles of North Korea: How Real a Threat?," World Policy Journal 17 (Fall 2000), p. 13.

${ }^{91}$ This possibility is discussed with respect to the two South Asian countries in Hilary Synnott, The Causes and Consequences of South Asia's Nuclear Tests, IISS Adelphi Paper 332 (Oxford: Oxford University Press, 1999) pp. 7374.

${ }^{92}$ The "interplay" between disarmament, deterrence and missile defenses is noted in Ronald F. Lehman II, "Nuclear Deterrence and Disarmament After the Cold War," in James Brown, ed., Old Issues and New Strategies in Arms Control and Verification (Amsterdam: Vu University Press, 1995), p. 352.

${ }^{93}$ On the former, see Avinash K. Dixit and Barry J. Nalebuff, Thinking Strate- gically: The Competitive Edge in Business, Politics, and Everyday Life (New York: Norton, 1991), pp.168-186. On mixed strategies where unpredictability is not the aim, see Thomas Schelling, The Strategy of Conflict (Cambridge, MA: Harvard University Press, 1960), pp. 175-186.

${ }^{94}$ The same might be said for complete abolition, but such a pure strategy really seeks to replace arms control.

${ }^{95}$ It might be interesting, for example, to chart the changing mix over time (at least in terms of Western viewpoints). In the late 1960s and early 1970s, the management approach dominated in the era of the NPT, the SALT talks and détente. But by the early 1980s, abolition and nullification were both on the rise at the expense of management, with anti-nuclear movements and the proponents of SDI pursuing their respective agendas. From the late 1980s to the mid 1990s, one might say that nullification was increasingly out of favor, with abolition and management appearing to work in tandem as the Cold War ended and disarmament hopes for the post-Cold War period bloomed. But especially since 1998, nullification has again come to the fore.

${ }^{96}$ For a call for "new and creative approaches that embrace both deep cuts and defenses," see Krepon, "Missile Defense."

${ }^{97}$ For the argument that within the U.S. bureaucracy, "there is now widespread agreement that counter-proliferation and nonproliferation are complementary," see Roberts, "Rethinking N+1," p. 79.

${ }^{98}$ It is probably inaccurate (as well as politically incorrect) to refer to other WMD (such as chemical weapons) as the "poor man's nuclear bomb." Nuclear weapons are themselves the bargaining tool of choice for some poor states. ${ }^{99}$ For an example of this political taxonomy, see the diagrams in H.R. Kedward, Fascism in Western Europe 1900-45 (Glasgow \& London: Blackie, 1973), p. 240. I am indebted to my colleague James Watson for this reference.

${ }^{100} \mathrm{~A}$ similar point is made in Freedman, Evolution, p. 414. For a recent argument that combines strong support for both abolition and missile defenses (by U.S. General Charles Horner), see Schell, The Gift of Time, pp.41-5. ${ }^{101}$ Quoted in Freedman, Evolution, p. 413.

${ }^{102}$ James Dao, "Pentagon to Ask for Retirement of MX Missiles," New York Times, June 28, 2001, <http://www. nytimes.com>.

${ }^{103}$ U.S. Senate, Committee on Armed Services, Statement of the Honorable Donald H. Rumsfeld prepared for the Confirmation Hearing Before the U.S. Senate Committee on Armed Services, January 11, 2001, <http://www.senate. gov/ armed_services/statemnt/2001/010111dr.pdf >.

${ }^{104}$ Gordon, "Bush, Missile Defense," p. 31. The authority cited in this context was General Vladimir Yakovlev, Commander-in-Chief of the Russian Strategic Rocket Forces.

${ }^{105}$ Final Document of the Review Conference of the Parties of to the Treaty on the Nonproliferation of Nuclear Weapons, Volume 1, Part I, p. 15.

${ }^{106}$ On Russia and China's insistence that references to stability, see Tariq Rauf, "An Unequivocal Success? Implications of the NPT Review Conference," Arms Control Today 30 (July/August 2000) <http://www.armscontrol. org/ACT/julaug00/raufjulaug.html>.

${ }^{107}$ New Zealand Ministry of Disarmament, Press Release, May 21, 2000, "NZ Shapes Global Agenda for Nuclear Disarmament."

${ }^{108}$ Remarks by President George W. Bush to Students and Faculty at National Defense University, May 1, 2001.

${ }^{109}$ Ibid.

${ }^{110}$ National Institute for Public Policy (NIPP), Rationale and Requirements for U.S. Nuclear Forces and Arms Control, Volume 1: Executive Report (Fairfax, VA: NIPP: January 2001), p. 3.

${ }^{111}$ See "U.S. to Tell China It Will Not Object to Missile Buildup," New York Times, September 2, 2001, at <http://www.nytimes.com>.

${ }^{112}$ Michael Krepon, "Moving Away from MAD,"Survival 43 (Summer 2001), p. 88.

${ }^{113}$ See Lewis A. Dunn and Victor Alessi, "Arms Control by Other Means," Survival 42 (Winter 2000/01), pp. 129-140.

${ }^{114}$ National Institute for Public Policy, Rationale and Requirements, p. 16.

${ }^{115}$ See Thomas C. Schelling, "The Role of Deterrence in Total Disarmament," Foreign Affairs 40 (April 1962), pp. 392-406.

${ }^{116}$ See Godwin, "China's Nuclear Forces," p. 265.

${ }^{117}$ For the argument, however, that America may be at its most vulnerable to WMD threats when pursuing its interests abroad, see Richard Betts, "The New Threat of Mass Destruction," Foreign Affairs 77 (January/February 1998), p. 40. 